SOFÍA ZASLASCKY

\title{
Dispositivo poÉtico
}

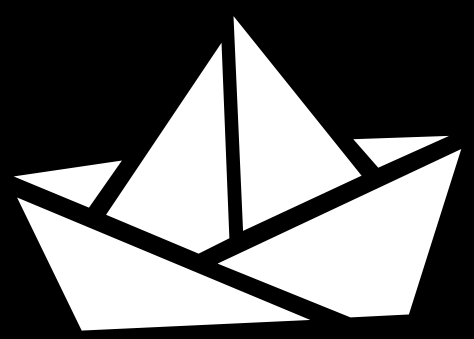


DISPOSITIVO POÉTICO 


\section{Dispositivo POÉTICO}

SOFÍA ZASLASCKY

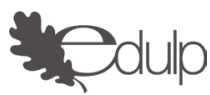


Zaslascky, Sofia

Dispositivo poético / Sofia Zaslascky. - 1a ed. - La Plata : EDULP, 2017.

Libro digital, PDF

Archivo Digital: descarga y online

ISBN 978-987-4127-34-1

1. Poesía Argentina. I. Título.

CDD A861

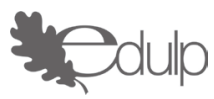

Editorial de la Universidad Nacional de La Plata (Edulp)

47 N. 380 / La Plata B1900AJP / Buenos Aires, Argentina

+542214273992/ 4274898

editorial@editorial.unlp.edu.ar

www.editorial.unlp.edu.ar

Edulp integra la Red de Editoriales de las Universidades Nacionales (REUN)

ISBN 978-987-4127-34-1

Queda hecho el depósito que marca la Ley 11723

(C) 2017- Edulp 


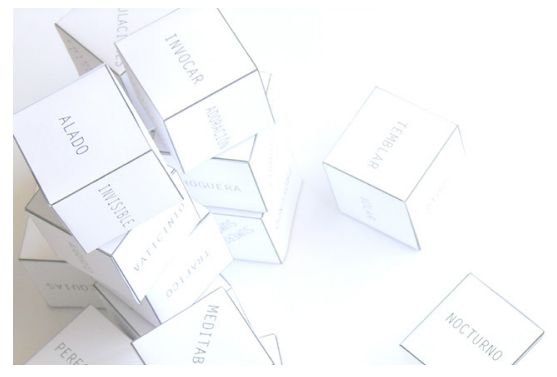

Para Osiel 


\section{Índice}

Introducción

El azar

Aleatoriedad

13

Poemas, o palabras arrojadas 


\section{Introducción}

Este libro es el registro fotográfico de un proyecto hecho en papel. No se trata de un trabajo quieto y congelado como la foto, este resultado es uno entre muchos otros posibles, nunca definitivos sino al contrario, se encuentran en un estado de permanente mutación.

Además de la lectura convencional de arriba hacia abajo y de izquierda a derecha, se puede abordar el texto estableciendo otros recorridos posibles, en los sentidos y direcciones que se deseen. Cada lector podrá armar y trazar su propio camino.

Los dados en las imágenes que siguen, tienen palabras en vez de números. Cada uno está organizado alrededor de una idea, por ejemplo hay uno en el que las palabras tienen que ver con el fuego:

centelleo
iluminar
oro
fulgor
hoguera
combustión


Otro con el aire:

\author{
atmósfera \\ volátil \\ inmaterial \\ alado \\ emanación \\ invisible
}

Seleccióné una muy pequeña cantidad de palabras arrojadas o poemas. Todos fueron elaborados con los dados. El resto queda en manos del lector. En sus manos y en sus ojos. 


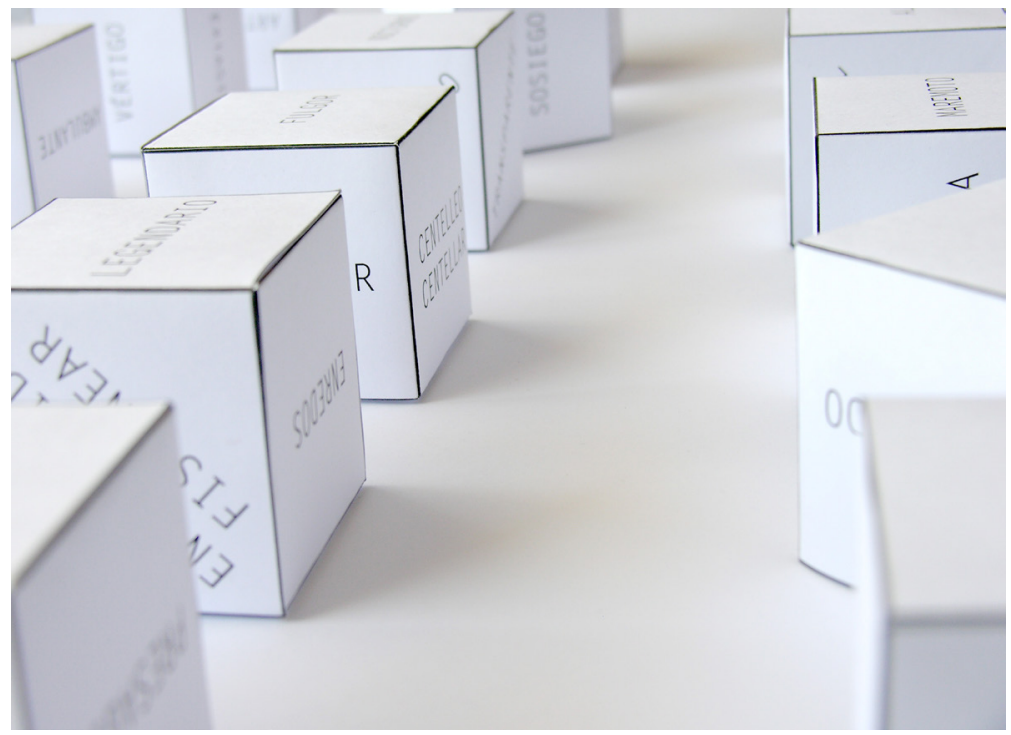




\section{El azar}

Fenómeno que ocurre de manera fortuita e impredecible, sin estar condicionado por la relación de causa y efecto ni por la intervención humana o divina.

Sin reflexión ni orden o sin una intención determinada.

De manera casual. 


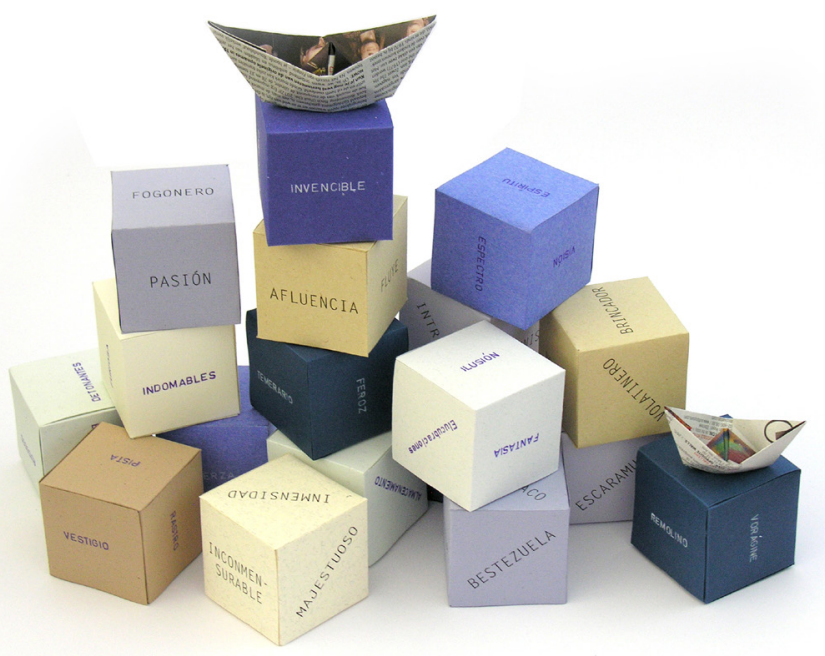




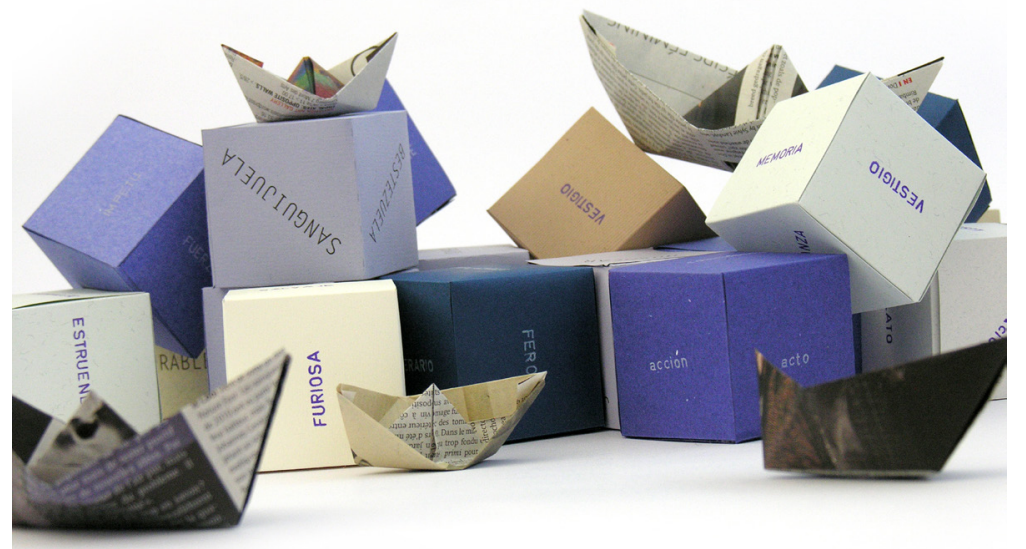




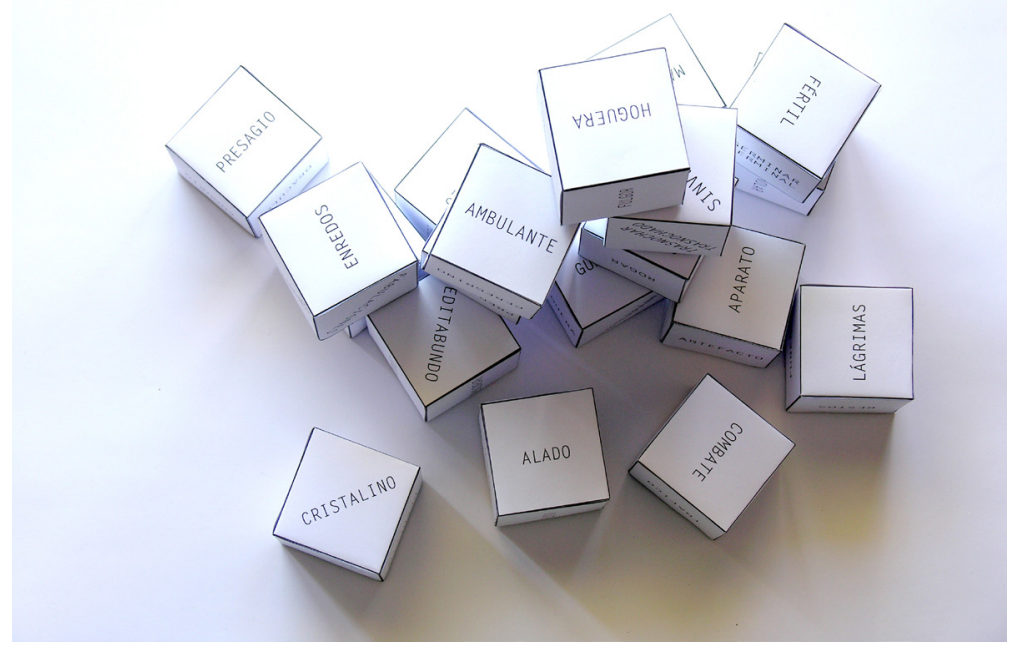




\section{Aleatoriedad}

Al revés de lo que sucede con la razón y la lógica, los procesos aleatorios no responden a causas y patrones predeterminados o predecibles, aunque pueden presentar características organizadas a algunos niveles.

Las coincidencias, las casualidades, tienen una explicación un orden, pero no se nos es revelado.

Esta forma de entender lo irracional es una posibilidad tan legítima como su opuesto.

La coincidencia es información que también podemos procesar e incorporar, tal como sucede con los oráculos. 


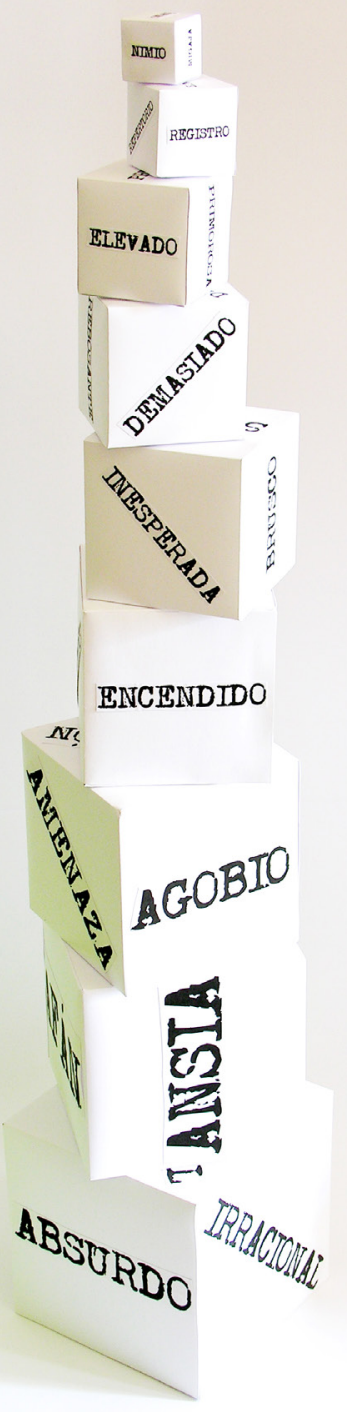




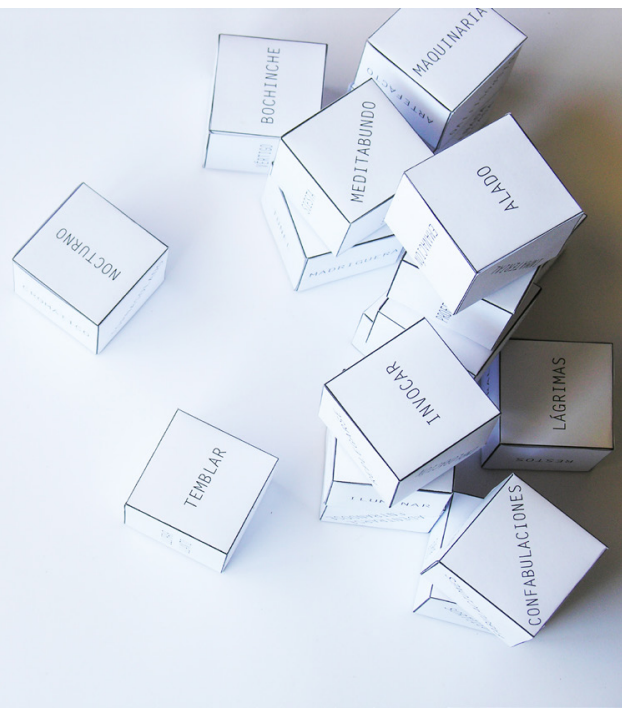




\section{Poemas, o palabras arrojadas}

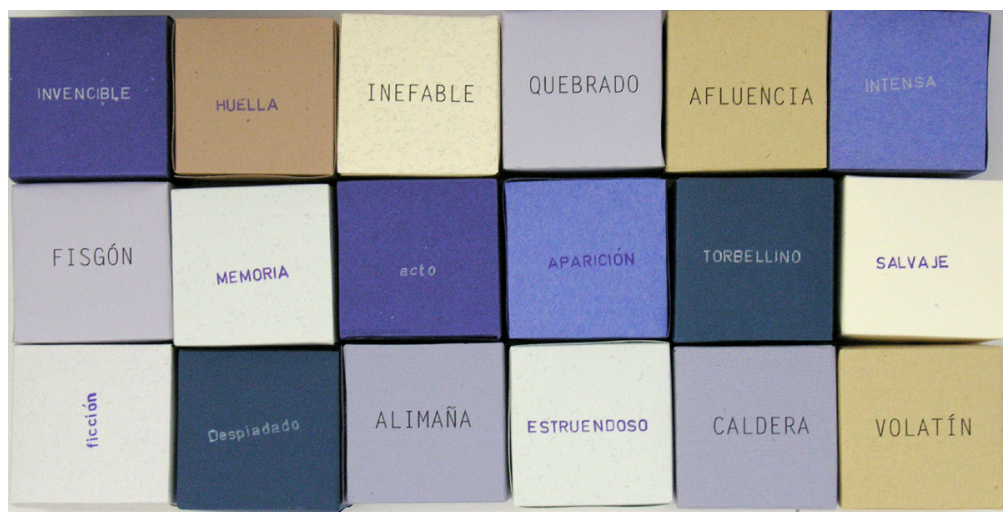




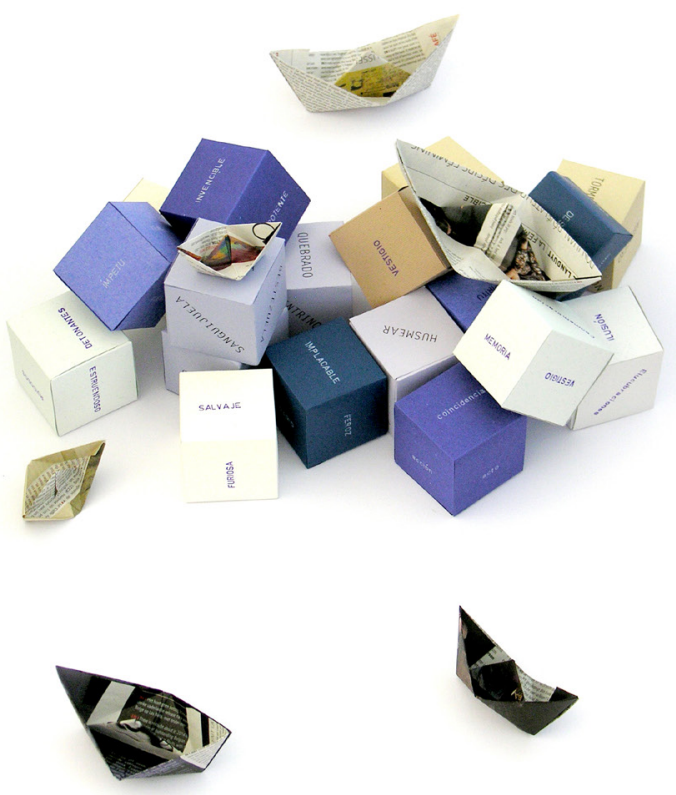


Hoguera brillante revuelta

recitando

habladurías.

Embrujo relámpago

Inmaterial tráfico nómade transparente

Oscuro susurrar serenidad

augurio subterráneo

Maquinaria despedida. 


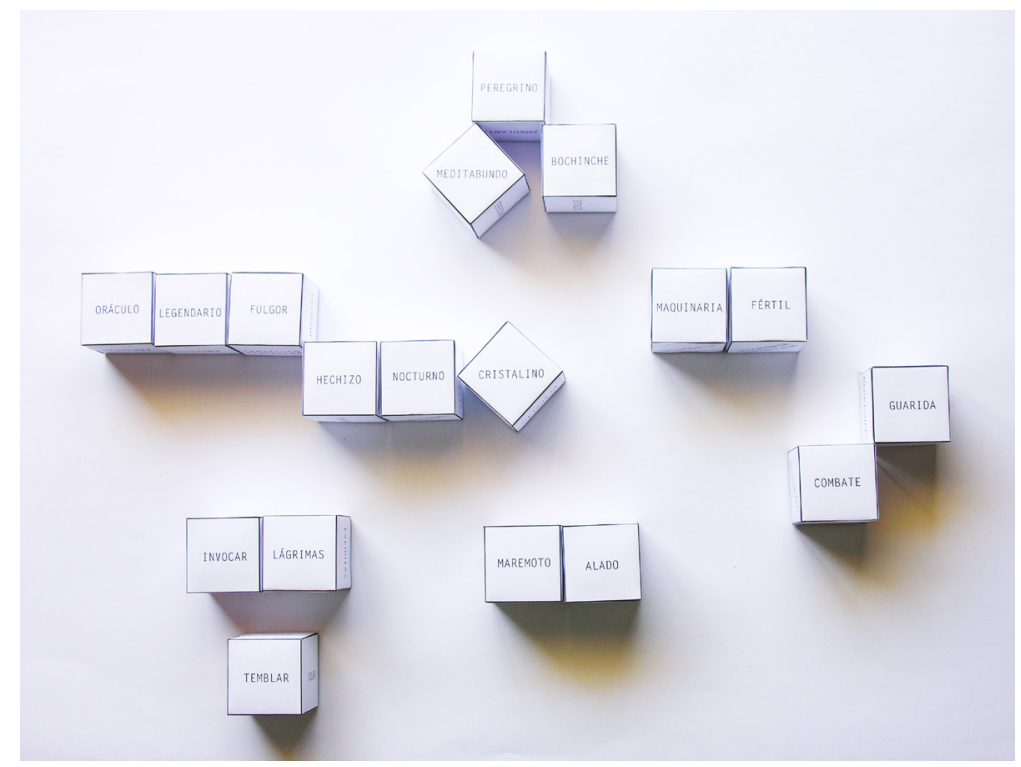



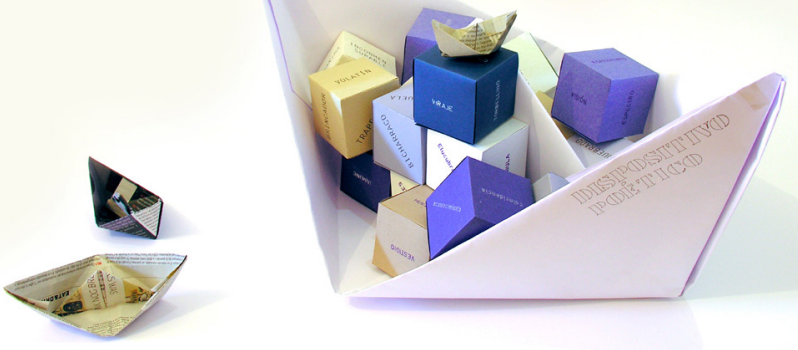


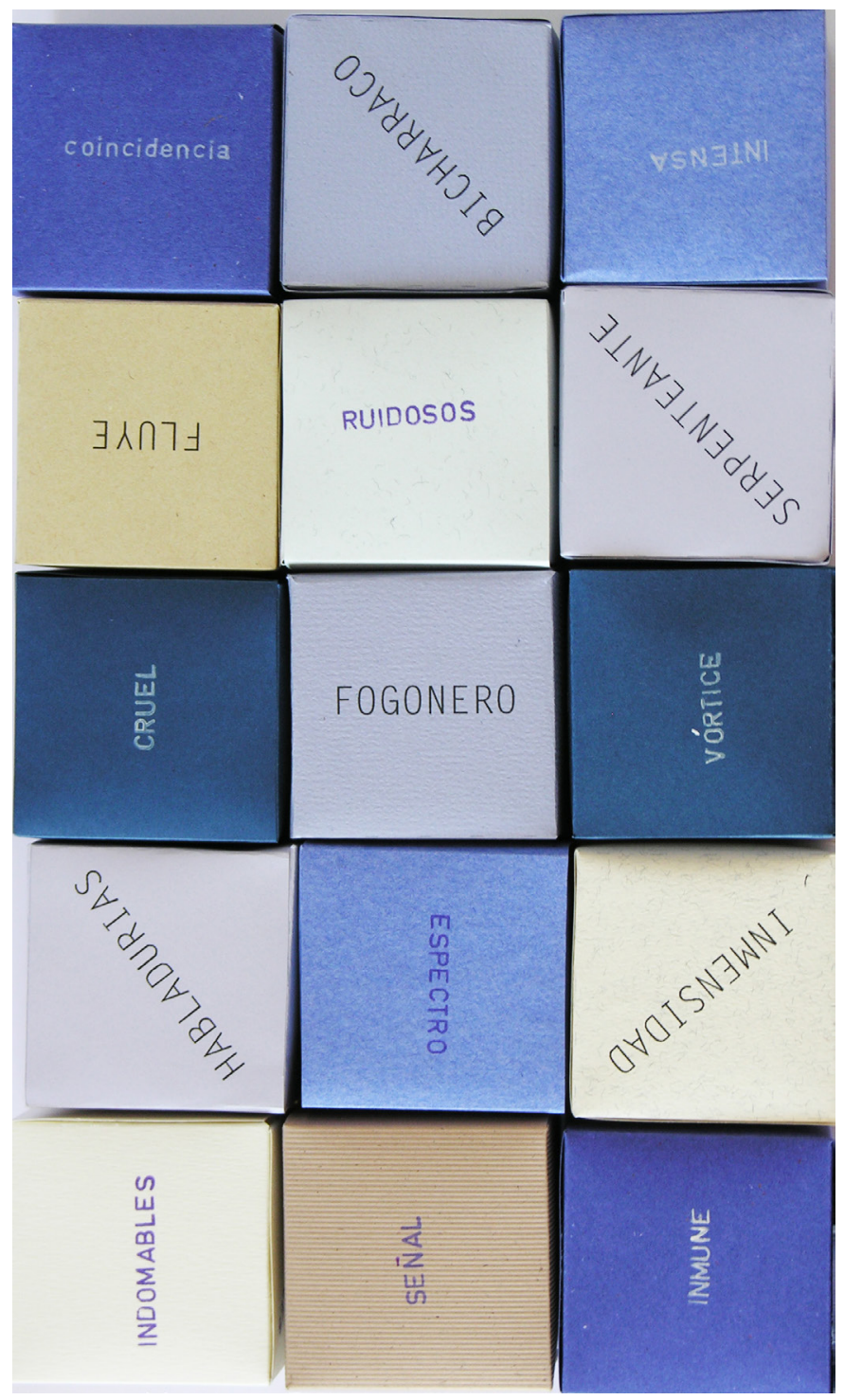


Traficante eterno,

artilugio volátil ambulante

adentrándose sudando

Encanto nevado

Meditabundo

bochinche 


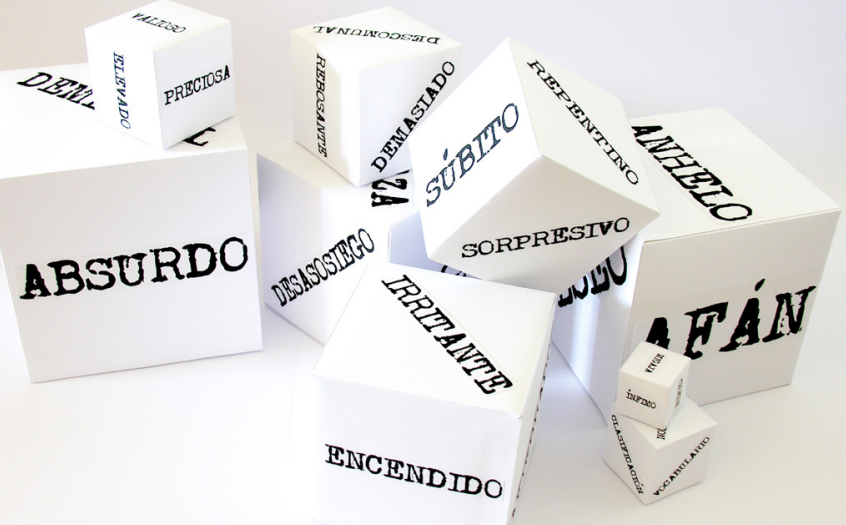




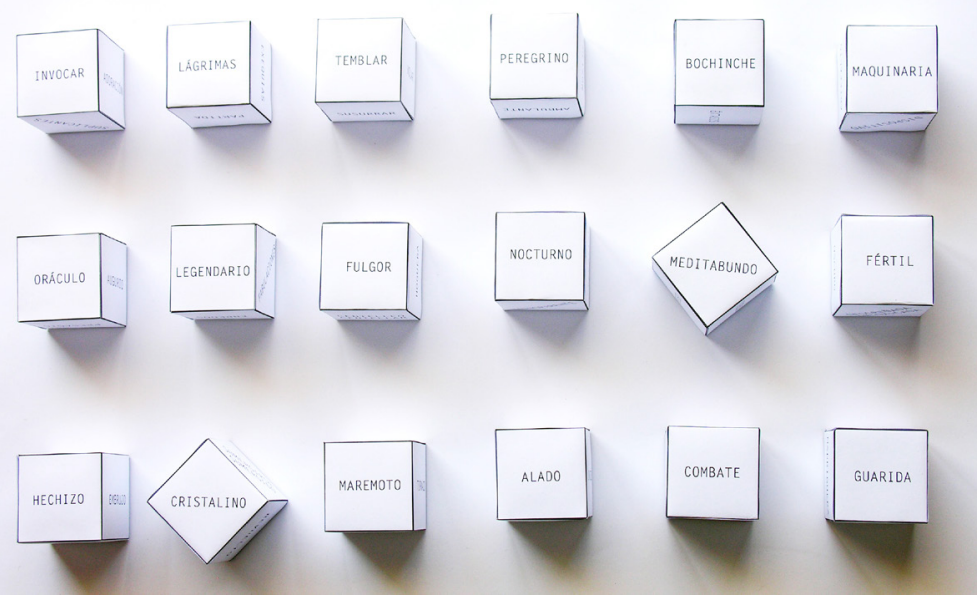


Presagio húmedo,

andariegos depredadores

tormenta fértil.

Susurro trasnochado

invocando enredos nocturnos.

Instante

Maquinaria alada

lágrimas subterráneas

conjuros 


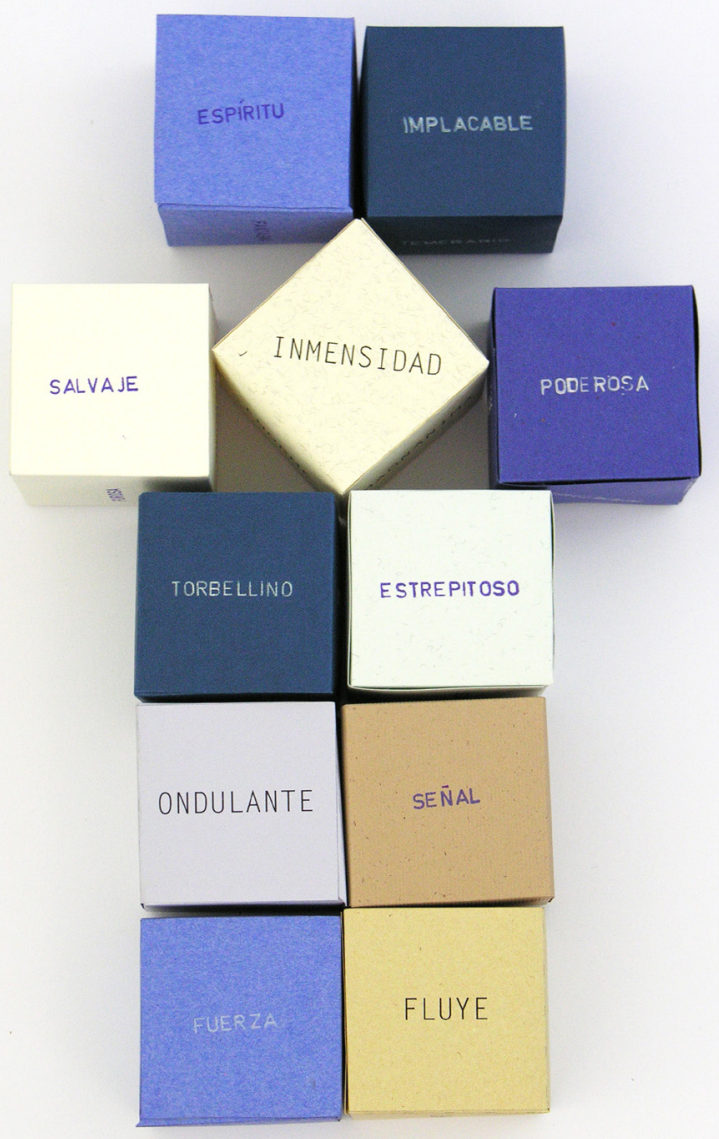




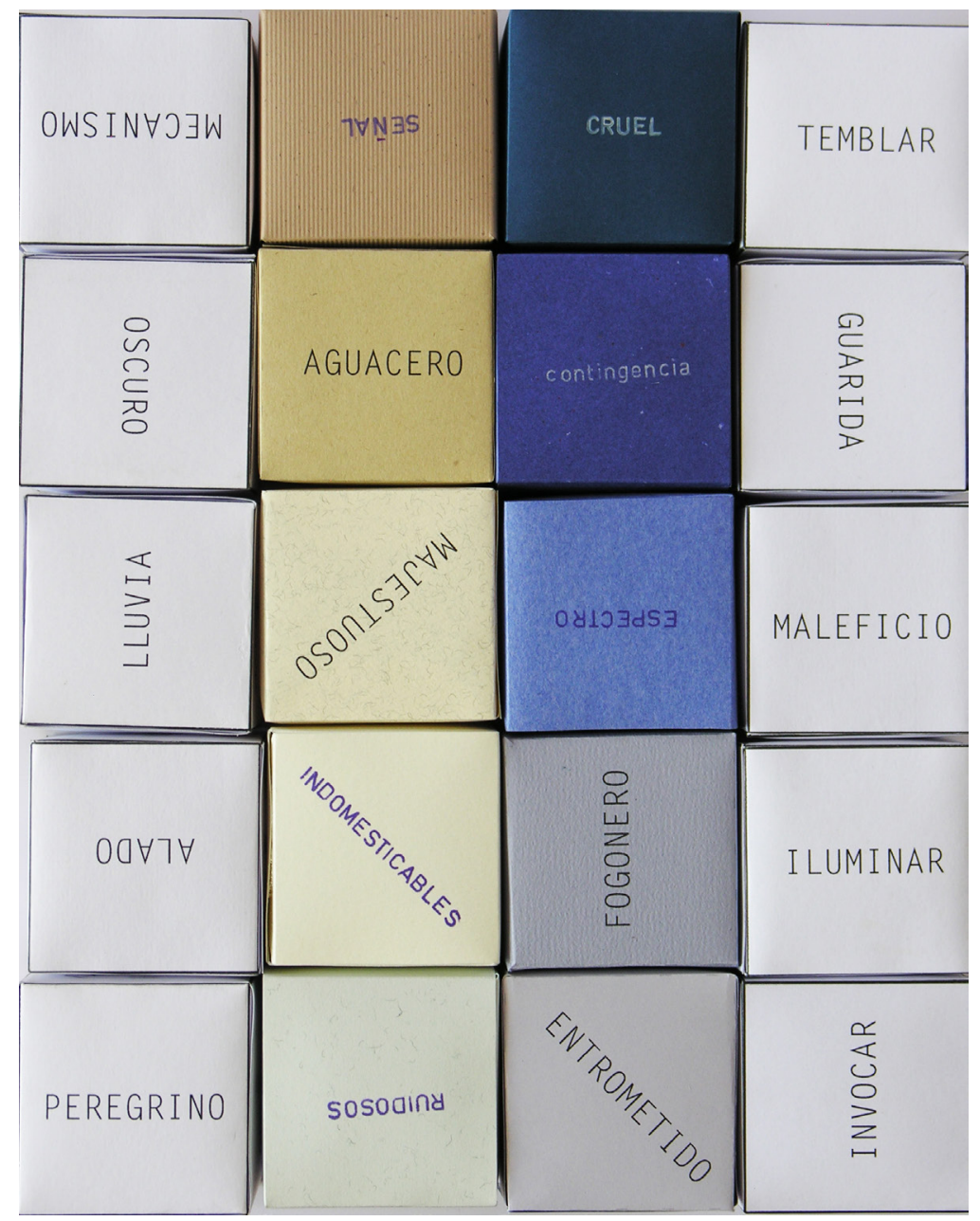


Vértigo alado

explosión inevitable.

Súbitas siluetas desnudas

posan nocturnas,

irreverentes. 


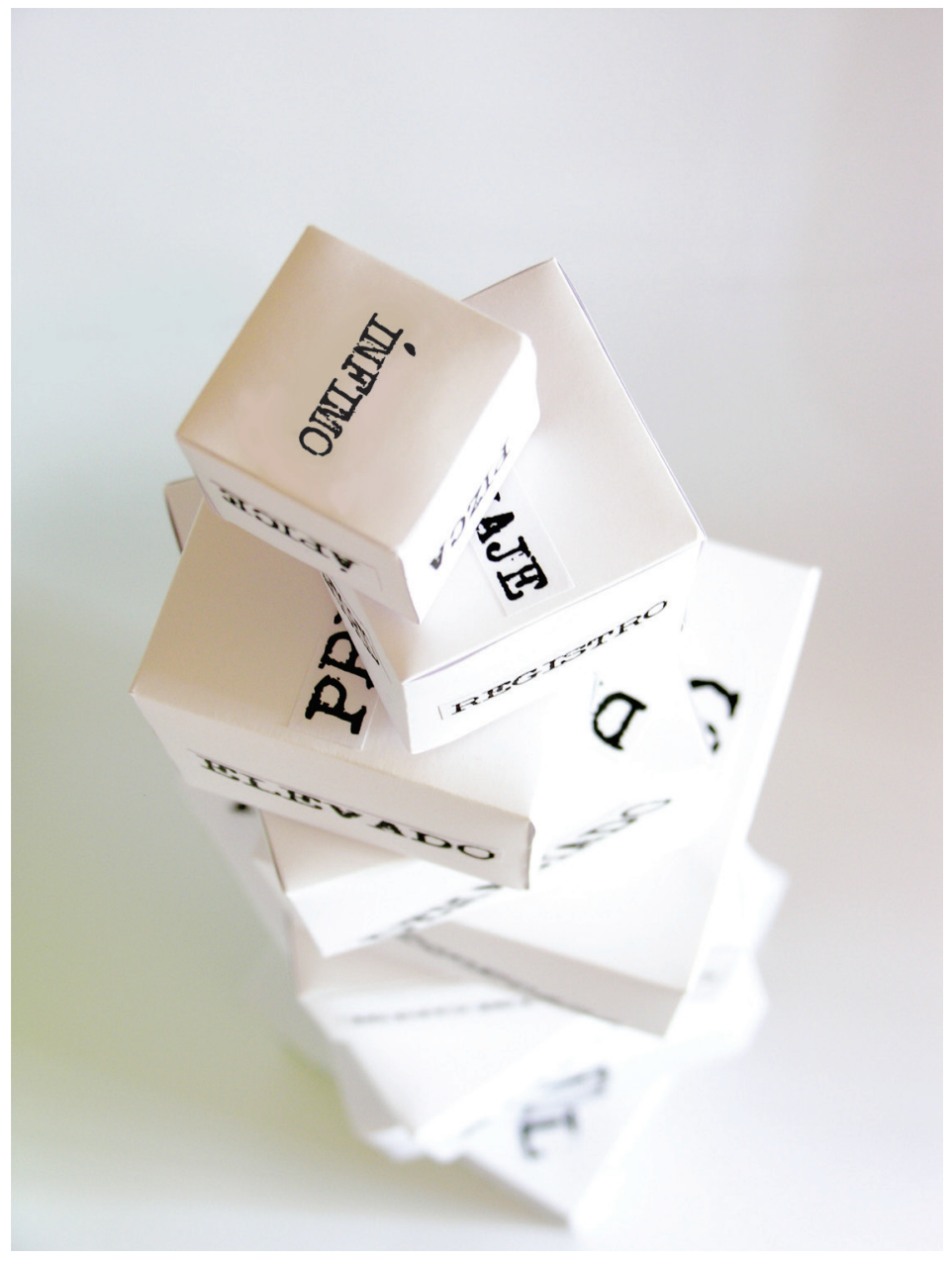




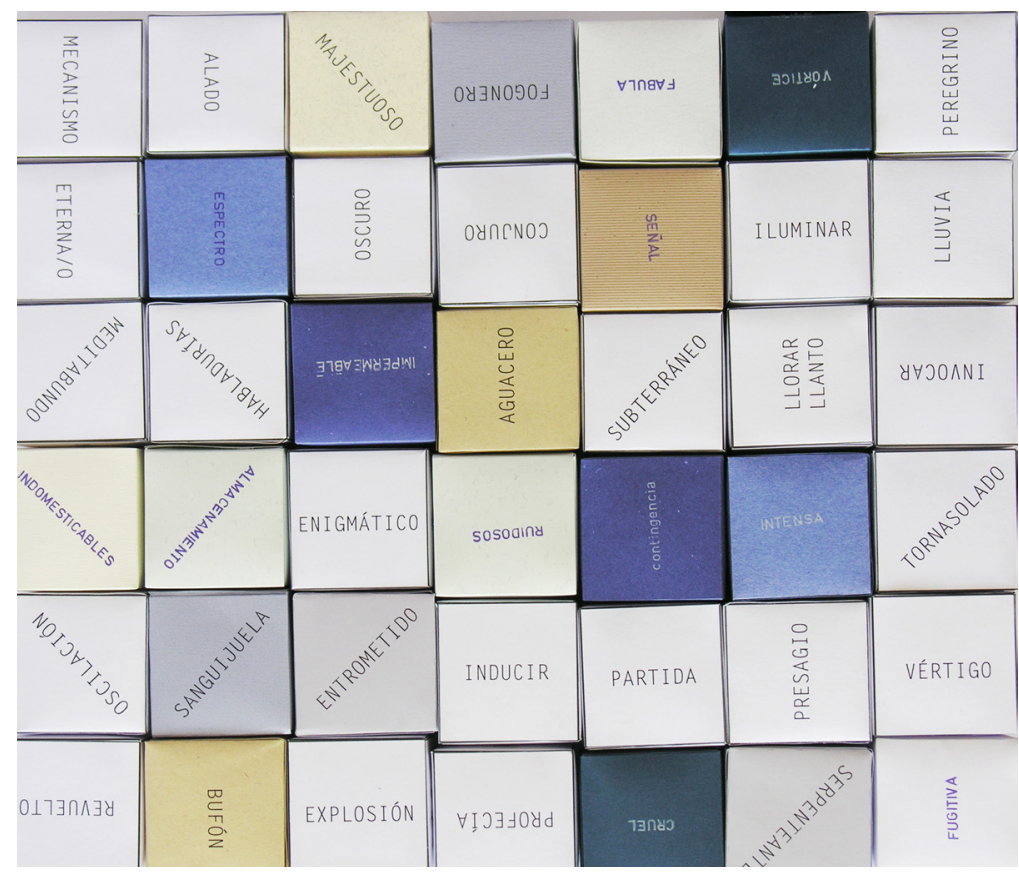




\section{Despedida,}

invisible artilugio intoxicado

vaticinio adentrándose llorando expediciones

hechizados sótanos legendarios,

nevados combates

tornasolado remolonear

rogando silencio. 


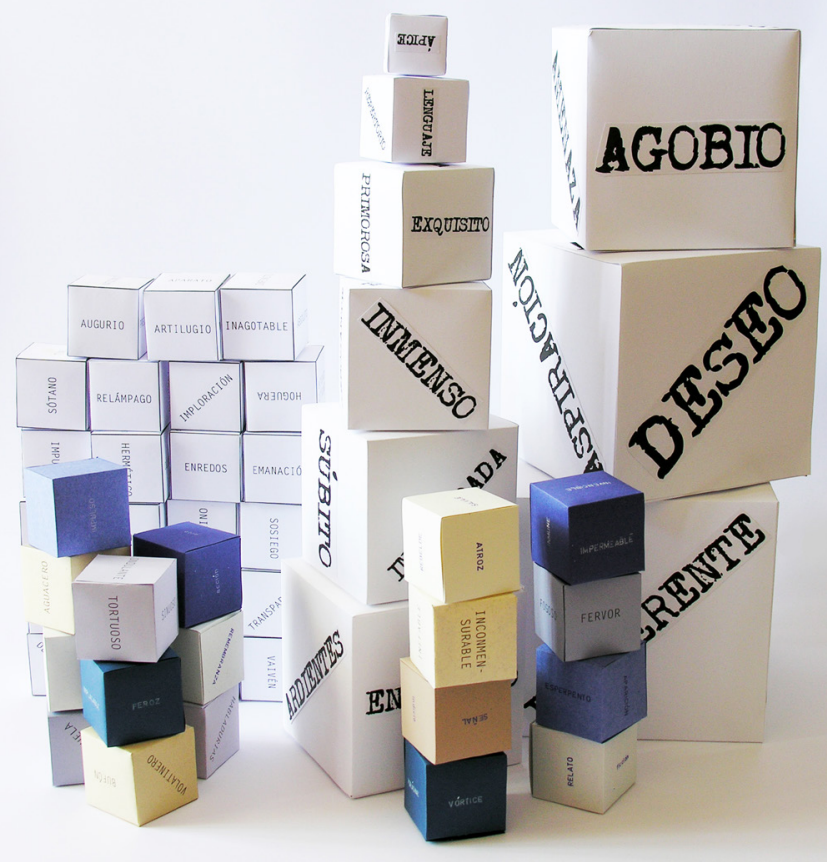




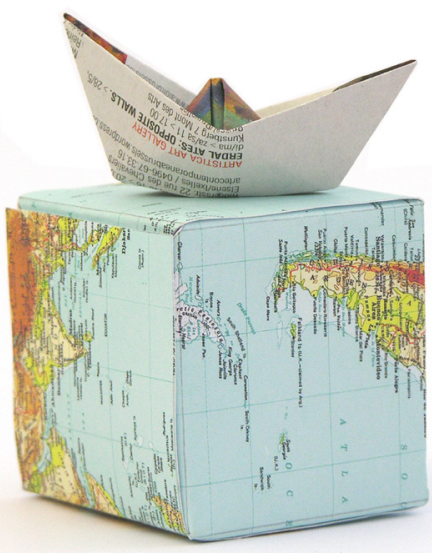


*dulp 
Este libro es un experimento, un procedimiento que adaptado adecuadamente puede ser utilizado de muchas otras maneras. Sin embargo aquí se empleo para componer poesía.

Cada uno de los dados en este libro, esta conformado por seis palabras organizadas alrededor de una idea. Por ejemplo hay uno que tiene que ver con la eternidad: Absoluta, interminable, infinita, inerte, inagotable, inmortal.

Otro con lo secreto:

Enigmático, confidencial, hermético, ilegal, recóndito, intimo.

Dispositivo poético es un modo de agrupar palabras, de combinarlas entre sí formando un mar de lenguaje. Revueltas o quietas, mutando permanentemente, fluyen una y otra vez.

Las fotografías aquí, contienen texto, es decir que en este caso la imagen es para leer. Además de la lectura convencional, de arriba hacia abajo y de izquierda a derecha, se pueden abordar estableciendo otros caminos posibles, en los sentidos y direcciones que se deseen. Cada lector podrá navegar armando y trazando su propio recorrido.

Sofía Zaslascky nació en La Plata en 1981. Estudió Escultura en la Facultad de Bellas Artes de la Universidad Nacional de La Plata.

Desde hace varios años realiza además talleres de escritura y artes escénicas.

En su producción artística trabaja en diferentes disciplinas y medios como la fotografía, la escritura, la ilustración, el diseño y la escultura entre otras.

Desde hace un tiempo viene realizando diferentes objetos en papel y en el año 2013 comenzó a explorar con los dados, así nació Dispositivo Poético, un proyecto en el que continúa trabajando actualmente.

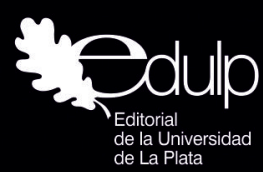

